\title{
Research and conceptual cages in the International Political Economy of South American Regionalism
}

\author{
Investigación y jaulas conceptuales en la economía \\ política internacional del regionalismo sudamericano
}

\section{Pesquisa e gaiolas conceituais na economia política internacional do regionalismo sul-americano}

\author{
iD (9) Ernesto Vivares \\ Faculdade Latino-Americana de Ciências Sociais (FLACSO Ecuador), Quito, Ecuador \\ eavivares@flacso.edu.ec
}

iD Lorena Herrera-Vinelli

Instituto de Altos Estudios Nacionales, Quito, Ecuador lorena.herrera@iaen.edu.ec

\begin{abstract}
This article analyses the multiple, contrasting roles and limitations of the dominant IPE regionalist theories in the research about the New South American Regionalism. The article focuses on the methodological dimensions of each research approach, at the North and the South, analyzing the role of theory in research by the deployment of the Weberian concept of 'iron cages.' The paper critically examines two levels of categories in global conversations, one international and the other regional, which gathers dominant ideas used in research on the IPE regionalism. The first level groups the South American perspectives from inside the region and anchored in dialogue with different international theoretical orientations. These are: the market-led perspective, the multilateral developmentalist, and the post developmental views. The second level of categories includes the Eurocentric regionalism, liberal
\end{abstract}


integration theory, and actor-oriented North American regional perspective.

Keywords: Regionalism. International political economy. Liberal integration theory.

Resumen: Este articulo analiza los múltiples y contrastantes roles y limitaciones de las teorías dominantes de regionalismo en EPI en la investigación sobre el Nuevo Regionalismo Sur Americano. El artículo focaliza en las dimensiones ontológicas, epistemológicas y metodológicas de cada enfoque de investigación, en el Norte y en el Sur, analizando el rol de la teoría en la investigación bajo el uso del concepto Weberiano de "jaulas de hierro". En consecuencia, el artículo identifica y discute dos niveles interrelacionados de conversaciones globales, uno internacional, el otro regional, ambos conceptos extendidos y utilizados en la investigación sobre la EPI del regionalismo. El primer nivel de categoría son las perspectivas Sur Americanas desde dentro de la región y ancladas en diálogos con diferentes orientaciones teóricas internacionales, tales como: la perspectiva basada en el mercado, la de desarrollo multilateral y la post-desarrollo. Las segundas categorías son de naturaleza internacional e incluyen el regionalismo Eurocentrista, la teoría liberal de la integración y la perspectiva regionalista norteamericana focalizada en los actores.

Palabras clave: Regionalismo. Economía política internacional. Teoría de la integración liberal.

Resumo: Este artigo analisa as teorias regionalista dominantes do IPE por meio de um contraste, que considera os múltiplos papéis e limitações em jogo nas discussões do novo regionalismo sul-americano. O artigo enfoca as dimensões ontológica, epistemológica e metodológica de cada abordagem de investigação, no Norte e no Sul, assim como o papel da teoria na pesquisa e na implementação do conceito weberiano das "gaiolas de ferro". Consequentemente, o documento identifica e analisa dois níveis inter-relacionados de categorias em debates globais, um internacional e outro regional, conceitos amplamente utilizados na pesquisa sobre o IPE do 
regionalismo. O primeiro nível de categoria é a perspectiva sul-americana dentro da região, ancorada no diálogo com diferentes orientações teóricas internacionais, são elas: a perspectiva centrada no mercado, a multilateral desenvolvimentista e a pós-desenvolvimentista. O segundo nível de categoria, de natureza internacional, inclui: o regionalismo eurocêntrico, a teoria da integração liberal e a perspectiva norte-americana orientada para os atores. Palavras-chave: Regionalismo. Economia política internacional. Teoria da integração liberal.

Data de recebimento do artigo: 27/03/2019

Data de aprovação do artigo: 21/05/2019 
Research and conceptual cages in the International Political Economy of South American Ernesto Vivares • Lorena Herrera-Vinelli

\section{Introduction}

There has been an extense and passionate debate regarding the politico-economic nature of South American regionalism both before and after the decline of Pink Tide and concerning the return of neoliberal conservatism to the central region for the comprehension of the Global Political Economy (GPE). Supporters and detractors of either progressivism and neoliberalism, for long, have anchored their arguments to underlying assumptions about the outcomes of the reciprocal and dynamic interactions between world order, regionalisms, and above all, development. For some scholars, that is a matter of which theoretical perspectives are right or wrong, for others, it is a problem of methodology and research. Indeed, the academic discussion crosses the borders of different disciplines and theoretical perspectives, reframing how the research is done, in what Burgess (1982) resumes as the multiple roles of the theory in research. That is from testing to refining theories and concepts.

By deploying the Weberian concept of 'conceptual cages,' this article analyses different international and regional perspectives about the South American regionalism. Briefly, the paper identifies and discusses two interrelated categories of extended concepts used in research on the IPE regionalism. The first are the South American perspectives, anchored to different dialogs with the international: The market-led perspective, the multilateral developmentalist, and the post developmental views. The second category, the international conceptual cages, are related to key dominant interpretations such as the Eurocentric regionalism, liberal integration theory, and actororiented North American regional perspective.

The work examines the ontological, epistemological, and methodological assumptions underlying these perspectives and how they are used in the research about the politico-economic of regionalism and development. According to WEBER (2001), the 
Research and conceptual cages in the International Political Economy of South American Ernesto Vivares • Lorena Herrera-Vinelli

use of certain concepts for current research, removed from their original meaning and political purposes, can justify the expansion of existing powers rather than explaining social changes. Weber (2001) calls such historical ideas, 'long lasting iron cages'. These iron cages are ideas based on rationalized forms of how reality functions within a given historical context (Weber, 2001). The Weberian metaphor is a useful concept to identify, analyze, and avoid conceptual cages concerning the IPE regionalism. The aim is to advance a research agenda concerning more eclectic, plural and integrated IPE and regionalist perspectives which can account for other realities concerning development than the Anglo-Saxon and Western world (ACHARYA, 2011; DUNNE; HANSEN; WIGHT, 2013).

The article is structured as follows. First, we outline debates within IPE regarding the New South American Regionalism (NSAR) and their different orientations. Second, we move on to identify the primary sources of IPE nurturing the comprehension of the relation between regionalism and development in different research frames. Third, we deploy the concept of conceptual cages by examining three dominant identified perspectives. Finally, conclusions are advanced, highlighting the importance of pluralist and eclectic research in the GPE of regionalism unlocking some Anglo-Saxon and Western conceptual cages.

\section{Debates, methodological derivations, and conceptual} cages

The discussion concerning the politico-economic nature of the NSAR centers on whether it represents a historical structural opportunity of development or a threat that stems from the decline of the liberal order and the transformation of the Americas. Or, if this is merely another episode in the historical regionalist struggle around two ideological projects (market or state-led development). Underlying the debate, there is a set of dominant academic perspectives of development disputing the comprehension of the 
Research and conceptual cages in the International Political Economy of South American Ernesto Vivares • Lorena Herrera-Vinelli

politico-economic nature of new regionalisms. This work contends that the source of these regionalist approaches rests, by and large, upon theoretical-methodological positions of a different academic network concerning what world order, regionalism, and development are. The paper claims that diversity, differences and even confusion around those can be found by analyzing the relationship between regionalism and the whole, and how the role of theory in research is defined (BURGESS, 1982; JACKSON, 2011).

Nowadays, few scholars would deny that the production of social knowledge in the International Political Economy (IPE) is interconnected with existent power relations. Nevertheless, differences and struggles are always in the nature of knowledge. That is the base of its development (COX; SCHECHTER, 2002; DUNNE; HANSEN; WIGHT, 2013, p. 406). Hence some believe that only hypothesis testing and covariation-causality produce knowledge in scholarly IPE. Others, instead, believe that the unique way is via reflection and developing better interpretations of reality. Independently of the fervor of their flag bearers, both are certainly part of the same historical production of knowledge of our time, and, out of their conceptual cages, they can take us to similar conclusions about what regionalism is at the time of research. The point is how to approach ontologically and epistemologically the research in the IPE regionalism to avoid the bias of some Anglo-Saxon and Western approaches (ACHARYA, 2011; DUNNE; HANSEN; WIGHT, 2013; JACKSON, 2011).

To start with, we need to explore and categorize how scholars situated themselves in the IPE regionalism, the role of theory in research for each case, and identify and analyze the concepts that bias research at the time of dealing with the global south and new regionalisms (JACKSON, 2011). If we want to get out of the conceptual traps and deal with the methodological riddles, a more open, critical, integrated and eclectic approach seems to be necessary to grasp the South American IPE way of regionalism. The first riddle or trap is the polemic around what the production of knowledge is. That is, whether hypothesis testing or reviewing 
Research and conceptual cages in the International Political Economy of South American Ernesto Vivares • Lorena Herrera-Vinelli

the assumptions and premises underlying the perspectives that nurture such hypotheses to refine understanding and produce refined concepts (DUNNE; HANSEN; WIGHT, 2013). By surveying the new contributions in the IPE regionalism, the evidence shows that scholars that follow a simple methodological way, one or the other mentioned, arepracticallyinexistentwithfewexceptions(QUILICONI, 2008; QUILICONI; SALGADO, 2014). There is the bias produced by the discourse and orientations of dominant approaches. For instance, the market-led regionalist perspectives dominant in Latin America and nurtured by the two academic strands of Eurocentric regionalism and economic liberalization fix the analysis to market outcomes, homogenous national convergence, and supranational institutionality. The position is that the European Union (EU), from a particular institutional and liberal understanding, is the obligatory model to follow and to which any regionalist projects should be compared (MALAMUD, 2011a). Amartya Acharya has coined this as Eurocentric Regionalism hiding a false universalism (2011, p. 631). Indeed, the Western view is theoretically underpinned by the notion that international history and development are the results of free trade and markets, supported by regional and international institutions (STEIN, 2008). Interestingly, the neoliberal and historical institutional argument was developed by functionalists and neo-functionalists. Accordingly, the ontology of regional cooperation is mostly economic and institutional, where the market, political convergence, and sovereign transfer from national states to regional institutions are conditions sine qua non of its existence (Malamud, 2011a).

The view, certainly quite popular amongst a network of Latin American scholars, stems from two central, but unrevised perspectives. One is the universalist and ahistorical interpretation of European regionalism. The other is the positivist North American political sciences tradition, centered on actor behavior, liberal economic integration, and neoliberal institutionalism (Söderbaum, 2013). That is a perspective from above whose production of knowledge rests upon hypothesis testing or covariation-causality. It assumes a universalistic mode of causal-logical inferences from 
Research and conceptual cages in the International Political Economy of South American Ernesto Vivares • Lorena Herrera-Vinelli

western experiences and analysis of data without revision of, neither, the theories that support the hypothesis nor their assumptions (i.e. the closed model KING; KEOHANE; VERBA, 1994, p. 9).

The second view focuses on the regional structural transformation of Latin America into South America and is called the multilateral developmentalist approach. It lays on the assumption that the exhaustion of Washington-sponsored regional multilateralism and its institutions, precipitated the return of the state, and presidentialist diplomatic regionalism (BONILLA; LONG, 2010; RIGGIROZZI, 2012; SANAHUJA, 2009). Its candidates argue that renewed regional integration emerges as a South American political coalition with new features. This is a focus upon social, political, and security dimensions, and standard policies in areas of energy and infrastructure. The political leverage of the NSAR is nurtured by the hegemonic differentiation and competition among North America, the EU, and South East Asia. With varied research focus, proponents of this view argue that the rise of the NSAR responds to three significant facts: the failure of the Washington-sponsored inter-American System, in particular, the Organization of American States (OAS), and the creation of the Union of South American Nations (UNASUR). The root of the change is 'from above', led by the state and the presidency, which has moved the axis from Latin to South America, opening the door to the surge of different multilateral regional alternatives, and the creation of regional security complexes by democratic administrations (BONILLA; LONG, 2010, p. 23-28). The major strength of these perspectives is its substantial and critical eclectic conceptual apparatus. Their weakness is the dispersion and embryonic nature of the empirical research with some notable exceptions, namely Estay and Sanchez (2005), Shaw, Marchand and Bøås (2005), De Lombaerde and Söderbaum (2014) and Riggirozzi (2012).

Finally, according to proponents of the post-development approach, the new world system of development forces the region into new paths of 'underdevelopment'. Those features represent a return to regional economic reprimarization, multiple rentier 
Research and conceptual cages in the International Political Economy of South American Ernesto Vivares • Lorena Herrera-Vinelli

states, and new asymmetries and inequalities, as well as social and political conflicts that threaten to destroy the conditions of existence of local societies (PETRAS; VELTMEYER, 2012; SCHULDT; ACOSTA, 2009; SVAMPA, 2013). This view represents an innovation, although with the risk of resting on universalist and economist interpretations about underdevelopment. Some of them generally focused on the study of isolated contextual and historical case studies around such as the Dutch disease; the Prebisch-Singer thesis; Bhagwati's immiserizing growth; or Ricardian rent. Scholars from this perspective argue that new Center-Left Extractive Regimes (CLER) have led this pragmatic strategy of development taking the opportunities of high prices via partnerships with multinational companies (MNCS) (PETRAS; VELTMEYER, 2012).

Followers of the first line of the debate argue that we are witnessing two different ideological, economic and regionalist projects. One is the market-led or the Pacific Alliance that follows the 'international conventional wisdom' of development. The other is the state-led or the New Lefts or neo-populists alternatives with developmentalist receipts of growth (DABÈNE, 2012; LUHNOW, 2014; MALAMUD, 2005; REID, 2009). Exponents of developmental regionalism assess the NSAR as a politico-economic opportunity given by the reconfiguration of Latin America, but with a severe risk. That is to say considering that it could be isolated from the geopolitical economy of the Americas and Washington. This is a geopolitical, economic change benefitting and facilitating the convergence of different national development strategies, all led by presidential diplomacies and focused on historical issues of regional development related to free trade and finance (BONILLA; LONG, 2010; RIGGIROZZI, 2012; SANAHUJA, 2009). Finally, for the post-development New Left, the new regionalism features a 'shift from import-substitution industrialization to dependence on agromineral export', someting embraced and led by 'center-left regimes resulting from popular movements which have overthrown neoliberal regimes' (PETRAS; VELTMEYER, 2012). Accordingly, the new central issues of development are still not addressed, and the region continues to face problems of politico-economic dependency on 
Research and conceptual cages in the International Political Economy of South American Ernesto Vivares • Lorena Herrera-Vinelli

the Global North. In the re-emerging field of Latin American IPE, the most dominant ideas concerning regionalism are, in some cases, biased by notions of Eurocentric universalism, liberal and North American actor-oriented regionalism. This is what some scholars still claim to be the foundation for conceptual development, theory building, and above all, the comparison model (ACHARYA, 2011; SÖDERBAUM, 2013).

Because of the overwhelming influence of North American academia and Washington-sponsored institutions in the last three decades, the academic production of Latin American IPE has mostly been tied, conceptually and methodologically, to North American and European approaches (DECIANCIO, 2016). The point is that increasingly IPE scholars are observing and pointing out that Eurocentric universalism and North American actor-oriented proves to be incomplete for grasping other regional developments. This skews, for hypothesis testing, notions such as integration, regionalism, hegemonic stability, national interest, and market economy. The matter is academically well known and already highlighted by an important number of scholars, who argue that it leads into methodological locks or conceptual cages (BUZAN; LITTLE, 2000; HIGGOTT, 2003; JACKSON, 2011; KATZENSTEIN, 2009; SMITH, 2006; TICKNER, 2003).

The methodological problem is to grasp how politico-economic concepts, underlying the views on regionalism, define the comprehension of development in the world order. Accordingly, one way is by identifying the politico-economic assumptions upon which they rest. That is to ask what is understood by international, global, or regional realities of development (ontology) and secondly how learning about them and their knowledge production occurs (epistemology). This helps us to identify and avoid the conceptual and methodological limitations of specific dominant ideas without loss of the academic gains of many research contributions (ACHARYA, 2011; DUNNE; HANSEN; WIGHT, 2013; HAY; PAYNE, 2013). 
Research and conceptual cages in the International Political Economy of South American Ernesto Vivares • Lorena Herrera-Vinelli

It follows then that the market-led regional perspective assumes the political and economical as two independent realms, governed by different logics and types of knowledge JACKSON, 2011). Free markets and trade drive world history, while politics either serve to underpin the economy, or risk turning it into an obstacle for development. Over there, the international is conceived as a mechanical system of units, where the sum of the parts (national economies) constitutes the whole. As a system, it tends to reach equilibrium, reducing conflict, lessening the power of the nation-state, and increasing the power of the markets. The limitation of this concept is its formal rationalist conception of regionalism and development, which is unable to grasp new conflicts and informality (new wars, borderless conflicts, organized crime, solidary economics, environmental crisis, human trafficking, and others).

In the case of the development regionalism view, the IPE is eclectic and heterodox, integrating and assuming pragmatically that the international and regional orders historically change but considering the inertia and geopolitical game of existent powers. Therefore, development paths can be different but complement each other within the same geopolitical regional space and multilateral configuration, representing a mixed ontology among power, newinstitutionality, and economicforceswithoutpredefining the particular outcome. Similar to market and institutionalist perspectives, it debates about reprimarization, new conflicts, as well as informal and environmental development. Finally, the postdevelopment perspective works on a critical but unrevised relation among power, politics, and economy, with the great virtue of having introduced new themes of post-developmentalism: ecological economics, and ethnicity. Its drawback is the absence of an alternative practical politico-economic conception of development beyond its focus on ethnicity and environmental rights. 
Research and conceptual cages in the International Political Economy of South American Ernesto Vivares • Lorena Herrera-Vinelli

\section{Diverse IPEs frame different meanings of 'development'}

The methodological issue with the concepts mentioned is that they bring limited or problematic assumptions regarding the politico-economic dynamic of the relations between regionalism and development. For many years, scholars have accepted certain concepts and methodologies as universal knowledge, without review, analysis, or debate about their validity. However, the 2008 global economic crisis shocked the dominant neoliberal model prevalent within academia, forcing scholars to rethink theory and research to grasp the changing world order, the rise of new regionalisms, forms of governance, and conflicts.

One way to classify that is by identifying those politico-economic views behind leading positions, both in terms of how regional development is conceived and by exploring how these theoretical perspectives define the ideas, politics, and economy that frame development. Working along these lines makes it possible to identify more eclectic approaches that can logically grasp and integrate diverse dimensions of development and regionalism. Some of them are agency-structure, formal and informal development, conflict and well-being, facilitating the contextual comprehension of divergent regionalist projects, modes, and levels of integration, as well as co-operation (DUNNE; HANSEN; WIGHT, 2013; LAKE, 2013; PAYNE; PHILLIPS, 2010; SIL; KATZENSTEIN, 2010). These ontological lines can help us to research about development as dynamics among ideas, politics, and economy, retrieving well-being or conflict in a given historical context within a specific world order.

For some scholars, the regional phenomenon ongoing in South America in the last two decades is part of what can be classified as 'new regionalisms' (DE LOMBAERDE; SÖDERBAUM, 2014; HIGGOTT, 2003; PAYNE, 2004). They have ascended within the frame of the new post-Cold War order with the crisis of neoliberalism, the exhaustion of the Bretton Woods institutions, and the weakness of the United Nations to handle international 
Research and conceptual cages in the International Political Economy of South American Ernesto Vivares • Lorena Herrera-Vinelli

conflicts. However, above all, they are firmly dependant on new configurations such as the rise of China and BRICS (BRESLIN et al., 2002). These changes have reshaped a complex world order where the new regionalisms, formal and informal, left or right wing-oriented, have taken the scene. The political economy of the new regionalisms is linked to the kind of response or reaction to the global order/s - from North Atlantic/Pacific and onto Eurozone PIIGS versus "second world"... of BRICS/CIVETS/MINT/MIST/VISTA (SHAW, 2000). They are first global conditioned by their domestic configurations. This new international scenario challenges us to rethink different assumptions/directions/implications about conflict and development, and above all, the place of regions and regionalism (SHAW, 2000).

Analytically, we do have a wide range of criteria and classifications to adopt and systematize regionalism, and all them bring specific forms of comprehension regarding development, the existent international order, and emerging powers. Different approaches represent different and even opposite epistemic communities and networks of production of knowledge (ACHARYA, 2011; DUNNE; HANSEN; WIGHT, 2013; SÖDERBAUM; SHAW, 2003). Some of them rest on distinctions between orthodox and heterodox methodologies, rationalist and reflectivist approaches, or interdisciplinary and disciplinary perspectives. However, given the necessity here of using a criterion capable of delimitating present and dominant IPE perspectives, we adopt a line based on the relation between knowledge and power manifested in epistemic networks. This assumes that social knowledge is aligned to particular projects of development and that always responds to existent pursuits of wealth and power of someone (COX; SCHECHTER, 2002). Indeed, knowledge has emerged bound or tied to different civilization powers (ACHARYA, 2011, p. 624-625). Moreover, that takes us to the question of whether North American and European centrism will have to contend with another centrism (Chinese, Indian or South American), to which the answer is no. That is part of a discussion that exceeds the extension of this work, although in 
Research and conceptual cages in the International Political Economy of South American Ernesto Vivares • Lorena Herrera-Vinelli

academic terms it is necessary not to lose the gains but identify and deconstruct the conceptual cages and methodological traps.

The classification of the world order can be adjusted, modified or enlarged, but from a Latin American perspective, it is central to focus on the role that different theories and concepts have played in the academic comprehension of the configuration and reconfiguration of the region. Following that, we adopt and adapt Benjamin Cohen's distinction between two major IPE perspectives defined by the power and networks of these, and add the Latin American view, which has reemerged as a growing epistemic network in the region (ACHARYA, 2011; COHEN, 2008). The distinction between a North American and British school is not new and is made by other prominent scholars in the field. According to Viotti and Kauppi, the division can be traced to the first decade after World War II, as 'British scholars did not embrace the behavioral movement that in the 1950s and 1960s that swept political sciences in North America (2012, p. 243). ${ }^{1}$. Hence, three main IPE perspectives and networks can be identified: The North American, The British and, after more than two decades of rejection and systematic degradation, a reviving Latin American IPE. Cohen makes the Coxian distinction between problem-solving theories, namely those that take 'the world as it finds it, with the prevailing social and power relationships and institutions into which they organize as the given framework of action' (COX, 1981, p. 88) and critical theories that address change and transformation in historical perspective, and which stand 'apart from the prevailing order and asks how order came about' (COX, 1986, p. 88).

This distinction is politically pragmatic, eclectic and regional basis and does not hide its political orientation, but assumes openly, that North American and British perspectives are defined as dominant academic schools produced by the North transAtlantic world order more than a national geographical locus. There are scholars on both sides whose work does not fall within the geographic allocation, namely Gilpin (2001) and Katzenstein

$\overline{1 \text { See also Bull (1966). }}$ 
Research and conceptual cages in the International Political Economy of South American Ernesto Vivares • Lorena Herrera-Vinelli

(2000). The criteria seek to identify negative and positive elements of the diverse theoretical perspectives on regionalism anchored to the main IPE perspectives identified as the initial step to build a research agenda for Latin American IPE. As Ruth Sautu (2003) points out, all research is theoretically constructed, assumed, or explained, and the theoretical formulation of a problem at all times defines the research approaches and methodologies adopted by scholars.

The first school is North American IPE (NAIPE) (COHEN, 2008; COX, 2009), based on the contributions of scholars such as Krasner (2000), Keohane (2002), Nye (2002), Frieden and Lake (2000), most of whom are former high-level US diplomats. The central concern of NAIPE is the stability and security of the international system. It assumes that the system is determined by universal and ahistorical market dynamics, as institutional rationality gives sense to any regional project. Its cornerstone is the concept that the international system is ruled by universal rationality, tending towards equilibrium, and whose epistemology is best conceived by neo-classical economics and actor-oriented positivist perspectives.

The primary concern of NAIPE is to explain how economic policies affect politics and vice versa, whose relation is conceived as a problem of articulation between two independent realms of development, governed by two different logics, and explained by two different sciences. These are political and economic sciences, each one defined by its own ontology, epistemology, methodology, and way to conduct research (FRIEDEN; LAKE, 2000; WALTZ, 2001). Their creeds are North American realism and neoliberal institutionalism, both claiming the inexorable globalizing destiny of free trade and finance based on the historical economic, political and institutional experience of Great Britain and the United States (KEOHANE, 2002; WALTZ, 1979). Generally, NAIPE scholars are adepts of positivist empiric research, given its precision and capacity to answer clear and direct delimited questions.

The other IPE school is the (erroneously named) British school (also known as 'pluralist' given the multiple perspectives 
Research and conceptual cages in the International Political Economy of South American Ernesto Vivares • Lorena Herrera-Vinelli

that have contributed to it) (COHEN, 2008; COX, 2009). Amongst its leading scholars are Susan Strange $(1986,1988)$ and Robert Cox $(1981,2009)$, while many of its adherents have been formed in the intellectual traditions of economic history, critical realism and Gramscian thought, as well as the ideas of Karl Polanyi (2001). Perhaps, its primary feature is that it does not account for an organized body of theories and concepts, let alone a standard or unique methodology. Instead, the central character of the pluralist IPE School (PIPE) is its openness to different theoretical perspectives and mixed methods to explain the change, conflict, and development. The PIPE of development is understood as an intellectual space of critical reflection focused on the research of the new complex process of change in historical and geographical contexts (COX; SCHECHTER, 2002, p. 76).

The primary concern of PIPE is how social reality is formed, in terms of how specific power relations produce realities and forms of governance within a given historical period. Central to its ideas is that parts must be understood to the whole and that the whole constitute more than the sum of parts. In that sense, international order is conceived as historical, where their social and economic structures never change, framing, and shaping development. Its major strength is the richness of its conceptual devices to understand the complex relations of structure-agency, international-domestic, state-markets, and conflict-development. Its significant weaknesses lie in the limited amount of empirical research, given the emphasis on conceptualization to understand change and conflict, as well as the complex relations between informal and formal development in regionalism, borderless states, ecology, and new wars.

Accordingly, agency and structure must be integrated into all analyses, where regionalism constitutes another dimension of development, something key to grasping the IPE nature of conflict and development (PAYNE, 2005). Thus, the research nature of the PIPE is eclectic, seeking to bridge the gap between theories and research - a multidisciplinary dialogue - different approaches and 
Research and conceptual cages in the International Political Economy of South American Ernesto Vivares • Lorena Herrera-Vinelli

methods. In many ways, the PIPE school is a heterodox relative of NAIPE, which is critical about the latter but also reflects in essential ways the trans-Atlantic ax of the world order in recent centuries. The two schools represent the two sides of a historical production of knowledge expressing the two academic histories post WWII, and therefore their networks and research from time to time interlink without clear limits between the two. There is a wide range of ontological, epistemological and methodological spaces of eclectic integration between the two perspectives in what Lake $(2013$, p. 572$)$ defines as the debate about the role of theory and the use of middle range theories in an eclectic and integrated form. Having outlined these two major academic schools in IPE, the following questions emerge: how have the North American and British schools related to the different and even opposite views regarding regionalism? Also, what is the relationship between these perspectives in the views and research concerning the regional dynamic of Latin America?

\section{IPE and theories of Regionalism}

While the debates concerning the political and economic nature of regionalism range widely, scholarly discussions about regionalism, such as in South America, have been dominated by NAIPE and Eurocentric conceptions (RIGGIROZZI, 2010). The large volume of regionalist research in Latin/South America rests upon an IPE that can be identified by four markers. First, the notion that the study of the agency of regionalism, focuses on governmental leadership, inter-governmental agreements, and formal integration processes in trade and customs, explains the nature of it. In this sense, it is taken for granted that regionalism is only built 'from above,' being always formal and institutional, what makes it a matter of international organizations rather than political economy of conflict and development. Secondly, there is 
Research and conceptual cages in the International Political Economy of South American Ernesto Vivares • Lorena Herrera-Vinelli

a strong tendency towards a biased interpretation of European regionalist experience, as a point of reference in scholarly research and the desired end-point of development. That is a conceptual and epistemological position driven more by the influence of certain academic institutions and regional powers than its scientific weight. Thirdly, it is the conviction in some academic spheres, inherited from and bound to the North American political sciences, that economics and politics are an independent dimension ruled by scientific logic. There the economic nature is always marketbased, and politics underpin it, and solely explicable through the scientific neo-positivist and institutionalist political methods. Fourthly, and finally, this kind of regional studies on LA rests upon a research format that negatively predefines its outcomes as these are based on unrevised theories or rationalizations of historical process alien to the region (e.g., the Industrial Revolution, the Cold War, European economic integration, regional institutions, and populism). This particular mode of production of knowledge is usually grounded on hypothesis testing or correlation studies. It is based on macro theories to which is applied the orthodox protocol of King, Keohane, and Verba (KKV), without recognizing that there is more than one methodological way of inference (JACKSON, 2011; LAKE, 2013; WALTZ, 2001).

Beyond that, there is a fair range of research upon regionalism that does not present the limitations nor the biases mentioned above. Those approaches do not deny the academic gains of decades and contributions from the Global North as they are adopted by many. However, they do not take as unquestionable some macro theories, dominant concepts or methodologies. An excellent strategy to avoid these theoretical limitations, barriers or conceptual cages and methodologies is to focus the analysis in three dimensions logically articulated in all substantive, eclectic and integral research: ontology, epistemology and methodology (ACHARYA, 2011; BURGESS, 1982; DUNNE; HANSEN; WIGHT, 2013; JACKSON, 2011; LAKE, 2013; SIL; KATZENSTEIN, 2010). Along these lines an essential body of research can be found in the works of 
Research and conceptual cages in the International Political Economy of South American Ernesto Vivares • Lorena Herrera-Vinelli

scholars such as Fredrik Söderbaum (2003, 2012, 2013, 2015); Adrián Bonilla and Long (2010); Björn Hettne (1997, 2003, 2006, 2008); Timothy Shaw (1988, 2000); Anthony Payne (1996, 2004, 2005) and Philippe de Lombaerde and Garay (2006). These scholars represent significant regionalist approaches, which are open and eclectic in their theoretical and methodological approaches.

\section{Regionalism: a multi-focus approach}

Regionalism can be grasped as the body of ideas, values and formal or informal, political projects that struggle for define realities (collective meanings, identities, agency, and structures) creating or transforming region within a particular world order. These political projects can be formal or informal, such as the action of transnational companies, organized crime, non-governmental organizations, informal economies, migration forces, diasporas or solidarity economies. Behind formal development, there is more than meets the eye. Generally, regionalism leads to the creation of regional institutions or governance networks and chains that can/cannot be part of hegemonic regional political projects (i.e., Inter-American System, UNASUR). Even more, regionalism can be formal, built 'from above,' or informal, created from the 'bottom-up,' escaping from the formal structures and sovereign power of nationstates. Examples of the latter are frontiers without states and their diverse informal political economies existents in the region (e.g., the triple frontier in Latin America, Ecuador, and Colombia, Venezuela and Colombia, Brazil and Paraguay). Therefore, regionalism does not always imply a transfer of sovereignty, through the creation of supranational institutions, as informal forces often regionalize faster than state authority. Hence, while regionalism usually coexists within the formal Westphalian order, it tends to transcend it socially and territorially. 
Research and conceptual cages in the International Political Economy of South American Ernesto Vivares • Lorena Herrera-Vinelli

The reconfiguration of the Latin American political economy after the Mexican crisis in 1994 is an example of non-formal institutionalized regionalism, something that took place more in the structure than in the regionalist agency of the traditional Inter-American System (PAYNE, 2004). To talk about regionalism, hence, does not only refer to formal interstate integration, but also to non-state actors, regional networks and social forces able to build regionalization and regional complexes of development. In that sense, integration and co-operation are, beyond their central academic importance, minor conceptual dimensions within the concept of regionalism, as the latter includes the former. Finally, we have the concept of regionalization, which is a multilevel notion that engulfs different structures and processes of regional formation (economic, ecology, energy, infrastructures, and social forces). These are substantive social constructions, which can be both formal and informal and that give structure to the region and around, where resources and power concentrate, defining multiples and inter-connected forms of development. A regionalist project can produce the regionalization of the area, but the region can emerge in its absence as the result of structural processes of regionalization (SHAW; MARCHAND; BOAS, 2005; SÖDERBAUM, 2012; SÖDERBAUM; SHAW, 2003).

There are two axes around which we can organize and analyze the relationship between the dominant perspectives of IPE and the variety of regionalist theories. Thus, we can order those regionalist perspectives centered and focused on formal constructions, actors-oriented, and based on institutionality, as a legitimate research focus. In contrast, the second research line perspective includes vast and complex issues of regional-national change (history, geopolitical economy, formal-informal, regionalismregionalization, and regional identities). 


\section{Successful ideas of one time can turn into 'conceptual cages' in another}

The idea that the mainstream IPE is biased towards certain preconceptions, concepts, and research practices is not new, once numerous scholars have pointed out how misleading assumptions and research practices implicit in Eurocentric regionalism, North American actor-oriented, or liberal economic integration perspectives have contributed to their failure to comprehend new regional processes and outcomes elsewhere (ACHARYA, 2011; JACKSON, 2011; RIGGIROZZI, 2012; SÖDERBAUM, 2013; TORRENT, 2003). According to Söderbaum (2013, p. 1), the problem inherent in the above approaches is their assumption that puts the European experience 'as the foundation for conceptual development, theory building and comparison', thus leading to a 'false universalism' based on a 'Eurocentric' reading of regional integration in the past.

The point is central since the study and evaluation of the new regionalisms, such as the Latin American, should be part of an eclectic and critical integrated research agenda in IR and IPE. That is because Latin America keeps a strong bond with the North American - European influence in the field of IPE, and above all in the comprehension of regionalism and its relations with globalization and development. There is relatively little research about Latin American contributions to IR along with IPE and in particular on regionalism out of the umbrella of both, the Eurocentric and North American market-led perspectives of integration. Different historical and academic factors have contributed to this but indeed, the dominant theoretical views in the region rest on neo-functionalism, institutionalist Eurocentric and North American perspectives, somehow caging the research (SÖDERBAUM, 2012, p. 5).

In The protestant ethic and the spirit of capitalism, Max Weber (2001) warned how successful ideas and projects of one era had been turned into political iron cages of another. According to Weber (2001), the use of certain concepts for current research, 
Research and conceptual cages in the International Political Economy of South American Ernesto Vivares • Lorena Herrera-Vinelli

removed from their original meaning and the political purposes given to them by their founders, usually justify the survival and expansion of existing powers rather than explaining social change. Weber (2001) calls such historical ideas, namely those with a strong political sense in their orientation of development, "long-lasting iron cages' of ideas, derived from rationalized forms of how reality functions in one historical context. The Weberian metaphor is a useful concept as a basis to identify and analyze the theoretical and methodological elements that are necessary in order to avoid the biases of Eurocentric, North American actor-oriented, or liberal economic integration perspectives on regionalism.

The main issues with Eurocentric regionalism and the North American actor-oriented or LEI lie in the architecture of the paradigms where they rest and reductionist assumptions concerning the role of theory in research on regionalism and IR, the base of its 'false universalism.' Conceptual cages can be identified as they do frame issues of development, set hierarchical assumptions, thus enclosing research and production of knowledge. In other words, they constitute epistemic practices that distort, depoliticize, and then turn them into technical concepts concerning specific projects of development (Bøås; Mcneill, 2004, p. 1-4). The epistemic power of them, as theoretical and methodological lenses, ends in a transformative logic that takes research generally toward a focus on ahistorical, top-down and liberal-institutionalist analyses and assessments of other regionalist experiences (BØÅs; MCNEILL, 2004; SÖDERBAUM, 2013).

These conceptual cages are marked by an excluding tendency to block other agency - structure dynamics out of the formal regional processes such as informal processes, conflict, and development (SHAW; MARCHAND; BOAS, 2005; TAYLOR, 2010). Conceptual cages function as consensual epistemic devices, and they depend and extend according to the power of epistemic communities. They legitimize and operationalize a particular ontological hierarchy of assumptions. The work is done in stages, first depoliticizing historical or contextual concepts of development, 
Research and conceptual cages in the International Political Economy of South American Ernesto Vivares • Lorena Herrera-Vinelli

then operationalizing them into technical and objective theories, so that in the last stage the conceptual frameworks can be used to measure or test to what extent other realities fit the mold (Bøås; Mcneill, 2004) This is what is behind the recognized trend between Latin American scholars to 'self-depreciate' the comprehension of its regional dynamics of development, as these never reach the Eurocentric, North American or other Western standards (HALUANI, 2006).

\section{Eurocentric regionalism}

Eurocentric regionalism is a conceptual cage subordinating any regional research framework to a rationalization of the European experience. It explicitly or implicitly sets a hierarchy of legitimate knowledge based upon a depoliticized reading of European regionalism, hiding the complex, contradictory and conflicting politico-economic processes behind its historical construction. Its central assumption is that the conditions sine qua non for any successful regionalism is a) peace and b) transfer of sovereignty from national powers to supra-regional institutions. Following Söderbaum (2013), this assumption is deeply associated with the first theoretical debates concerning the nature of European regionalism.

Indeed, the successful creation of the European Union (EU) is, to an extent, indebted to the historical purpose of ending centuries of horrific wars between neighboring authoritarian empires and nationalistic movements, which, counting only the two world wars, resulted in nearly 90 million deaths in the region (Leitenberg, 2006). In the case of Latin American regionalism(s), there is no comparative example. Moreover, the notion of sovereignty transfer to supranational structures represents a political concept derived and sponsored by the United States, who heavily insisted on the creation of superregional institutions to diminish nationalist conflicts 
Research and conceptual cages in the International Political Economy of South American Ernesto Vivares • Lorena Herrera-Vinelli

- in contrast, the United Kingdom (UK) feared and opposed a deeper integrated Europe (CAROLAN, 2008). The complex epistemic process of rationalization, starting with Mitrany's functionalism and subsequently Haas' neo-functionalism, were theoretical responses to rationalize European regionalism under a pragmatic, technocratic and institutional system based on the utilitarian calculus of individual actors (HAAS, 1975, p. 12).

Following Malamud (2011b), we can identify three other subelements central to theoretically and methodologically grasping the concept of Eurocentrism. First are Mitrany and Hass' functionalist and neo-functionalist paradigms, which associate regionalism with institutional integration and, in the end, with the idea that this implies a cession of state authority (2011b, p. 222). Mitrany (1966) believed in the historical challenge to overcome the problem of European nationalism and the competence between political units by learning from the experience of the North American New Deal. This functionalist concept was developed by institutional and liberal perspectives. Moreover, it proposes that the existence of regionalism and integration depends heavily on institutions and the deconcentration of power from states (Haas, 1975).

The second element is the subordinate relation of politics to a particular form of understanding economic development. Followers of this idea generally assert that economic integration follows from economic expansion through logical and linear stages, a concept formulated initially by Bela Balassa (1961). Finally, there is the existence of the third element, that of the extended and unrevised notion of 'convergence' and 'homogeneity' within and of a region (DABÈNE, 2012, p. 5; MALAMUD, 2011a). Accordingly, countries in a given area are said to give up their sovereignty 'voluntarily' and converge around common and concentric regional projects (MALAMUD, 2011a). Common projects thus direct regionalism without different structures in the same region or differences in national power or national poles within the same region. In the case of Portugal, Germany, France, or Poland, they would all have the same conditions of political power within the regionalization of Europe. 
Research and conceptual cages in the International Political Economy of South American Ernesto Vivares • Lorena Herrera-Vinelli

\section{Liberal Economic Integration}

Perhaps the most used and dominant conceptual cage in Latin America is the Inter-American System and its academic networks for understanding regional integration and regionalism. The LEI approach commonly cements the relation between - and is the basis of - the economic assumptions upon which neorealism and neoliberal institutionalism are conceptually integrated. Accordingly, regional economic integration is the foundation and objective of any serious regional project, a process that develops from the bottom up through a logical and linear sequence of market integration stages (e.g., free trade areas, customs unions, common markets, monetary unions, and economic integration).

Ironically, such a logical sequence of economic integration stages has never occurred in any significant historical case of regionalization, in particular, the EU (Torrente, 2003). LEI is probably the most academic construction of all conceptual cages, developed by economists seeking to depoliticize the nature of regional integration based on liberal institutional assumptions. The epistemic device rests on an extensive network of scholars on both sides of the Atlantic, who frequently connect with Bretton Woods institutions (ESTEVADEORDAL; SUOMINEN, 2007). As mentioned, the construction of LEl based on liberal institutional assumptions was developed by economists who positioned a particular perspective about integration. Consequently, LEI is an epistemic device of research that frames alternative policies of development, via depoliticization and technification of alternatives of integration based on assumptions of free trade.

One of the most important exponents of liberal economic institutionalism is the Hungarian-born economist Bela Balassa (1961). Marked by the concerns of the Cold War, Balassa embraced free markets and worries with the re-establishment of Western Europe as a world power based on liberal institutional and free-market 
Research and conceptual cages in the International Political Economy of South American Ernesto Vivares • Lorena Herrera-Vinelli

developments decontaminated from politics as an idealist framework (MACHLUP, 1977). LEl rests on the idea of a linear progression from preferential trade areas to free trade areas, with customs unions, common markets, monetary unions, and ending up with a complete economic regional integrated area, generally is the basis of most of the research on regionalism in regional development banks. These theories are concerned principally with the possible welfare effects stemming from trade creation, diversion, and integration (CABLE; HENDERSON 1994), although they present rigid limitations to explain development given their disciplinary economist boundaries integrally.

LEI economic approaches are usually used in combination with actor-oriented theories, to generate models to predict and enhance paths of interstate cooperation and measure liberal economic integration (ESTEVADEORDAL; SUOMINEN, 2007, p. 4). In this sense, there are two different lines of economic integration research. The first one concentrates on whether the impact of economic regionalism contributes to the world trading system. The second one, also created to explain economic integration in Europe, distances itself from orthodox economics by focusing more on investment, employment, infrastructure, and structural transformations, as well as market and government failures (ROBSON, 1993). The advantage of the latter approach is that it provides the conceptual grounds to explore regionalism in developing regions. Its primary disadvantage is the absence of research regarding heterodox experiences and politico-economic processes of regionalization, such as those seen in South America. Indeed, liberal regional economic integration still offers a vast and rich field of research that can integrate more heterodox perspectives on the impact of alternative strategies of growth based on the experiences of developing regions. The key in this regard is to bridge economics and politics by transcending the rigid disciplinary boundaries and unrealistic assumptions of problemsolving or actor-oriented approaches (SÖDERBAUM, 2005, p. 231). 


\section{Actor-oriented North American regional perspective}

The last conceptual cage presented here features for its capacity to methodologically bond rational choice, neorealism and neoliberal institutionalism perspectives by an epistemology defined by its method and 'scientific' procedures rather than an ontology of the reality (Lake, 2011). Actor-oriented's North American regional perspective (NARP) has come to share common ontological and epistemological premises with the Eurocentric school within mainstream IR theory as the result of the behavioral movement and modernization theory that embraced, in the decades following the end of WWII, North America, Europe and Japan (VIOTTI; KAUPPI, 2012). The development and focus of it are a trademark of the conservative wing of the traditional North American political sciences' school, unfolded today in what is termed as Open Economy Politics (OEP), a sort of subfield of the Strategic Choice approach in North American IR (BATES, 1997; FRIEDEN; ROGOWSKI, 1996; LAKE, 2011). NARP examines South American regionalism from the perspective of its institutional degree and trade variation vis-à-vis the 'standards' - Europe, North America, and Asia-Pacific.

NARP is heavily defined by two elements that rely on key implausible theoretical assumptions and whose main claim is that its methodology and procedures are the only scientifically acceptable for producing scientific knowledge in IR (HAY, 2002, p. 9; JACKSON, 2011, p. 43). It does nothing to do with the proved fact that in specific cases, neo positivist methods are the most appropriate to find answers to central research questions on integration and regional institutions. Instead, NARP utilizes in a particular way the classic hypothetical deductive method, where science is all about testable hypothesis under ceteris paribus conditions (contexts) that do not need explanations but isolation to define $Y$ and $X$, dependent and independent variables. The cage is its particular way to produce knowledge via a methodological approach, the KKV model, regarded as the only scientific method 
Research and conceptual cages in the International Political Economy of South American Ernesto Vivares • Lorena Herrera-Vinelli

based on universal rules of scientific inference in IR (Jackson, 2011; King; Keohane; Verba, 1994). Over there rests the rational choice assumption that agency (actor interests and decisions) from above produces regional development and that in order to grasp them is necessary to bracket preference actors over economic development. The second central assumption, its inherent politicaleconomic definition in terms of economic openness or closure via trade, is a paradigm inherited from trade policy and later extended to regional monetary and financial relations (LAKE, 2011, p. 48). Thus, regional research outcomes of this approach are metadefined by a particular view of development, that is, economic free trade integration rationalized in the analytical labyrinth of formal actors, and economic assumptions.

The second perspective in the iron cage of NARP is a specific concept derived from the neorealism perspective, the unrevised and extended idea from hegemonic stability theory (HST). According to that, without a hegemon, large state, willing to provide stability and economic growth through free trade and open markets, no region is possible. The typical argument there is that without Brazil or Mexico, assuming the hegemonic role to provide the regional leadership and necessary security, the Latin America regionalism is just a collection of different regional projects. Yes, that is a concept that clashes with the complex process of the regional multilateralism of NSAR, the role of Brazil and the power of Small States in. Neorealist regionalism focuses, from a hegemon that pursuit free trade and open markets, on the struggle and distribution of power within a particular region as the result of the links between security and growing economic interdependence (GOMEZ-MERA, 2008). For this singular way of neorealism, regionalism arises whenever cooperation is necessary for geopolitical reasons, following open economic tendencies (to counter the power of a rising regional power or to restrict the behavior of conflictive small state members in the region) (GRIECO, 1997). Therefore, for Neorealist, the regional hegemonic power is a necessary element and condition of regionalism as it promotes regional cooperation and institutionalization (HURRELL, 1995). 
Research and conceptual cages in the International Political Economy of South American Ernesto Vivares • Lorena Herrera-Vinelli

On the other hand, Neoliberal institutionalism meets, from an inside-out perspective, a group of functionalist and institutionalist theories emphasizing the importance of institutionalizing regional integration. It emerges from the central premise of liberal institutionalism, namely that regionalism is the rational response of governmental cooperation for solving the problems of an increased regional interdependence, such as the European experience (DEUTSCH; BURRELL; KANN, 1968; HAAS, 1958; MITRANY, 1966). Nowadays, neoliberal institutionalism is the dominant approach to regionalism in South America, marrying epistemologically neorealism and neoliberalism (KEOHANE, 1984; MANSFIELD; MILNER, 1997). Neoliberal institutionalism is stronger than its predecessor concerning its assumptions regarding the relationship between politics and economics. Here politics is shaped and limited by the allegedly 'universal' laws of neo-classical economics. Hence, states are constrained by market power, and their development is limited by a globalized economy dominated by trade and finance, firms, and markets. States respond to these challenges through regional trade agreements (trade regionalization), as global and regional economic integration is unstoppable, giving rise to the importance of institutions and regimes (KEOHANE, 1984). Regional trade agreements constitute the cornerstone of regional public goods as they are part of an incremental problem-solving process defined by the level of institutionalization and trade complementarity (SÖDERBAUM, 2005, p. 227).

\section{Conclusions}

The article has critically examined how mainstream theories on regionalism have limited the scope of an own research agenda about the NSAR. Fundamentally, from the analysis of three perspectives 
Research and conceptual cages in the International Political Economy of South American Ernesto Vivares • Lorena Herrera-Vinelli

such as Eurocentric regionalism, liberal integration theory, and the actor-oriented North American regional perspective. The adaptation and application of the Weberian concept "conceptual cages," allowed to identify how such political-economic perspectives on regionalism and development enclose a diversity of concepts and limited methodological formats that skew the comprehension of the NSAR. That is the typical case of the main "conceptual cages" of Eurocentric regionalism, which we found based on the premise of a successful integration process under the conditions of peacekeeping and the cession of the sovereignty of the states to a supra-regional instance. A view that ontologically and epistemologically depoliticizes the historical construction itself of European regionalism, concealing the international-regional political-economic processes inherent in its consolidation. The limitations of the concept for the NSAR are linked to the idea that regionalism should be assimilated and applied as a project based on an apolitical state-centric experience in a specific liberal world order with unique regional projects and without tensions between states and regional institutions. Briefly, the vision does not fit the Latin American experience, where integrationist and regionalist projects have instead failed in their attempts to achieve a high degree of institutionalization and sovereign transfer to regional institutions.

Regarding the liberal integration theory, we analytically found that it contains a linear approach that understands and assumes regional integration as a process that takes place in successive stages of economic growth. The central limitations there are linked both to the universalist postulates underlying it and to the notion of development based on western economic neoliberalism as the only formula of regional integration.

In the case of actor-oriented North American conceptual cage, the bias is defined by its empiricist epistemology, aligned with scientist neorealist political theories that make a non-contextual rationalist construction of regionalism. For instance, the neorealist assumption that the regional, like the international system, needs a hegemon to provide peace, economic growth, and discipline to the 
Research and conceptual cages in the International Political Economy of South American Ernesto Vivares • Lorena Herrera-Vinelli

fractious states. The problem is that this perspective only explains formal and institutional dynamics but no informal, non-state configurations and actors, and reorientations in the international that NSAR tends to produce. For example, although the weight of Brazil and Mexico has been relevant in terms of political and economic influence, these countries have not necessarily assumed a hegemonic role in shaping regional processes. Neither have they assumed the leadership to provide stability in aspects of interregional security.

In the case of institutional neoliberalism, we analytically identified that its central premise rests on the importance of institutions and, therefore, on the central assumption to achieve high levels of common institutionalization in regional integration processes. Three elements can be identified as the central weaknesses of neoliberal institutionalism to deal with NSAR. The first is the idea that regionalism is defined by its level of institutionalization subordinated to the dynamics of trade, and based on the regional experiences of the EU, NAFTA, and APEC. Secondly, there exits the identification of regionalism as a state-led project of integration, which confines the concept of regionalism and its research to states and governmental agencies, leaving out not only strategic areas of analysis but also questions of conflict and well-being. Finally, there is a reduction of regionalism to a trade phenomenon where institutions only play a role in creating incentives and constraints to given processes (SÖDERBAUM, 2005).

To sum up, the main limitations that these "conceptual cages" represent for an NSAR's research agenda are glimpsed in difficulty to explain regional specificities and generate new concepts, perspectives, and methodologies applicable to the domestic and international insertion of the region. 
Research and conceptual cages in the International Political Economy of South American Ernesto Vivares • Lorena Herrera-Vinelli

\section{REFERENCES}

ACHARYA, Amitav. Dialogue and discovery: in search of international Relations theories beyond the West. Millennium: Journal of International Studies, v. 39, N. 3, P. 619-637, 2011.

BALASSA, Bela. The theory of economic integration. London: Routledge, 1961.

BATES, Robert. Open-economy politics: the political eConomy of the WORLD coffee trade. Princeton: Princeton University Press, 1997.

BOAS, Morten; MCNEILL, Desmond. Global institutions \& development: fRAming the WORLd? New York: Routledge, 2004.

BONILLA, Adrián; LONG, Guillaume. Un nUeVo regionalismo sudamericano. Íconos: Revista de Ciencias Sociales, N. 38, P. 23-28, 2010.

BReSlin, Shaun et al. (Eds.). New regionalisms in the global political ECONOMY: THEORY AND CASES. LONDON: ROUTLEDGE, 2002.

BULL, Hedley. International theory: the case for a classical approach. World Politics, v. 18, N. 3, P. 361-377, 1966.

BURGESS, Robert. The ROLE OF THEORY In FIELd RESEARCH. In: BURGES, Robert (Ed.). Field research: a sourcebook and field manual. London: Routledge CuRzon, 1982.

BUZAN, Barry; LITTLE, Richard (EdS.). INTERNATIONAL SYSTEM IN WORLD history: Remaking the study of international relations. New York: OXford UNIVERSITY PRESS, 2000.

CABle, Vicent; Henderson, David (Eds.). Trade Blocs? The future of regional integration. London: Royal Institute of International Affairs, 1994. 
Research and conceptual cages in the International Political Economy of South American Ernesto Vivares • Lorena Herrera-Vinelli

CAROLAN, Bruce. The Birth of the European Union: US AND UK roles IN the creation of a Unified European Community. Tulsa Journal of Comparative \& International LaW, v. 16, N. 1, 2008.

COHEN, Benjamin. International political economy: an intellectual History. Princeton: Princeton University Press, 2008.

COX, ROBERT. SOCIAL FORCES, STATES AND WORLD ORDERS: BEYOND INTERNATIONAL Relations theory. Millennium: Journal of International Studies, v. 10, N. 2, P. 126-155, 1981.

COX, Robert. SOCIAL FORCES, STATES AND WORLD ORDERS: BEYOND INTERNATIONAL relations theory. In: KEOHANE, Robert (Ed.). Neorealism and its critics. New York: Columbia University Press, 1986.

COX, Robert. The 'British School' in the global context. New Political Eсопомy, v. 14, N. 3, P. 315-328, 2009.

COX, Robert; SCHECHTER, Michael (Eds.). The political economy of A PLURAL WORLD: CRITICAL REFLECTIONS ON POWER, MORALS AND CIVILIZATIONS. LONDON: ROUTLEDGE, 2002.

DABÈNE, OliVier. Consistency AND RESILIENCE THROUgh CYCLES Of REPOLITIZATION. IN: RIGGIROZZI, Pia; TUSSIE, DiAnA (Eds.). Rise OF POSt - hegemonic Regionalism: the CASE of Latin America. London: Springer, 2012.

DeCianCiO, Melisa. El regionalismo latinoamericano en la agenda de Relaciones Internacionales. Iberoamericana, v. 16, N. 63, 2016.

De lombaerde, Philippe; GARAY, Luis. The New Regionalism in Latin America and the Role of the US. In: International congress new linkages IN LATIN AMERICA: ECONOMIC INTEGRATION AND REGIONAL SECURITY, 2006, TOKYO. Annals... Tokyo: Sophia University and the Japan Center for Area Studies, 2006. 
Research and conceptual cages in the International Political Economy of South American Ernesto Vivares • Lorena Herrera-Vinelli

DE lOMBAERdE, Philippe; SOderbaUm, Fredrik (Eds.). Regionalism. BeLGIUM: SAGE-UN, 2014.

DeUtsch, Karl W.; BURRell, Sidney; KANN, Robert (Eds.). Political community in the North Atlantic. Princeton: Princeton University Press, 1968.

DUNNE, Tim; HANSEN, Lene; WiGHT, Colin. The end of international relations theory? European Journal of International Relations, v. 19, N. 3, P. 405-425, 2013.

eStay, Jaime; SANCHEZ, Germán (Eds.). El AlCA y sus peligros para América latina. Buenos Aires: ClaCSO, 2005.

ESTEVADEORDAL, Antoni; SuOMinen, Katı. Sequencing Regional trade INTEGRATION AND COOPERATION AGREEMENTS: DESCRIBING A DATASET FOR A NEW research agenda. Inter-American Development Bank, 2007.

FRIEDEN, Jefrry; LAKE, David A. (Eds.). International political economy: perspectives on global power and wealth. New York: St. Martin's Press, 2000.

FRIEDEN, JefFry; ROGOWSKI, Ronald. The impact of the international economy on national policies. in: KeOHANe, Robert; MilneR, Helen. Internationalization and domestic politics. New York: Cambridge University PRESS, 1996.

GILPIN, Robert. Global Political eConomy: understanding THE INTERNATIONAL political economy. Princeton: Princeton University Press, 2001.

GOMEZ-MERA, Laura. How 'NeW' is the 'NeW regionalism' in the Americas? The Case of Mercosur. Journal of International Relations and Development, v. 11, N. 3, P. 279-308, 2008. 
Research and conceptual cages in the International Political Economy of South American Ernesto Vivares • Lorena Herrera-Vinelli

GRIECO, Joseph M. Systemic sources of Variation in Regional institutionalization in Western Europe, East Asia and the Americas. In: MANSFiELD, Edward; MilneR, Helen (Eds.). The political economy of regionalism. New York: Colombia University Press, 1997.

HAAS, ERnst. The uniting of Europe: political, social and international organization. Standorf: Stanford University Press, 1958.

HAAS, Ernst. The obsolescence of regional integration theory. California: Institute of International Studies, University of California, 1975.

haluani, Makram. "How International" are theories in international Relations? The View from Latin America. In: INTERNATIONAL STUDIES ASSOCIATION, 2006, San Diego, California.

HaY, Colin. Divided by a common language? Conceptualizing power. In: hay, Colin (Ed.). Political analysis: a critical introduction. United States: Palgrave Macmillan, 2002.

hay, Colin; PAyne, Anthony. The great uncertainty. SPERI PaPer n. 5, 2013.

hetTNe, Björn. Beyond the 'new' regionalism. In: PAyne, Anthony (Ed.). Key debates in political eConomy. London: Taylor \& Francis, 2006.

HETTNE, BJÖRn. The double mOVement: GLOBAL MARKET Versus REGIONALISM. In: COX, Robert (Ed.). The new Realism: perspectives on multilateralism ANd world order. Tokyo: United Nations University Press, 1997.

HETTNE, Björn. The new Regionalism ReVISITEd. In: SÖDERBAUM, FredriK; SHAW, Timothy M (Eds.). Theories of new regionalism. Basingstoke: Palgrave MacMillan, 2003. 
Research and conceptual cages in the International Political Economy of South American Ernesto Vivares • Lorena Herrera-Vinelli

HETTNE, BJÖRn. Regional actorship and regional agency: comparative PERSPECTIVE. IN: 6TH GARNET PHD SCHOOL 'GLOBAL GOVERNANCE AND REGIONALISM', 2008, Brussels. Annals... Brussels, 2008.

HigGOTt, Richard. Alternative theories of economic regionalism: trade and finance in Asian Cooperation. Review of International Political Economy, v. 10, N. 3, P. 430-454, 2003.

HURRELl, Andrew. Regionalism in theoretical perspective. In: FAWCETt, Louise; HURRELL, Andrew (Eds.). Regionalism in world politics: regional ORganization and INTERnational order. Oxford: Oxford University Press, 1995.

JACKSON, PATRICK. The CONDUCt OF INQUiRY IN INTERNATIONAL RELATIONS: Philosophy OF SCIENCE AND ITS IMPLICATIONS FOR THE STUdY OF WORLD POLITICS. New York: Routledge, 2011.

KatZenstein, Peter J. Asian regionalism. New York: Cornell University PRESS, 2000.

KATZENSTEIN, Peter J. Civilizations in WORLd politics: pluRAL AND PLURALIST Perspectives. New York: Routledge, 2009.

KeOhane, Robert O. After hegemony: cooperation and discord in the world political economy. Princeton: Princeton University Press, 1984.

KEOHANE, Robert O. Power and governance in a partially globalized WORLD. LONDON: ROUTLEDGE, 2002.

KING, Gary; KEOHANE, Robert; VERBA, Sydney (Eds.). Designing In social inquiry: scientific inference in qualitative research. Princeton: Princeton UNIVERSITY PRESS, 1994.

KRASNeR, Stephen D. State power and the structure of international trade. In: FRIEDEN, JefFry; LAKE, David A. (Eds.). International political 
Research and conceptual cages in the International Political Economy of South American Ernesto Vivares • Lorena Herrera-Vinelli

ECONOMY: PERSPECTIVES ON GLOBAL POWER AND WEALTH. 4tH. EDITION. BOSTON: ROUTLEDGE, 2000.

LAKE, David A. TRIPS across the Atlantic: theory and epistemology in IPE. In: PHILLIPS, Nicola; WEAVER, Catherine (Eds.). International political eConomy: Debating the PASt, PRESent ANd future. New York: Routledge, 2011. LAKE, DAVID A. TheORY IS DEAD, LONG LIVE THEORY: THE END OF THE GREAT DEBATES AND tHE RISE OF ECLECTICISM IN INTERNATIONAL THEORY. European Journal of International Relations, v. 19, N. 3, P. 567-587, 2013.

LeitenberG, Milton. Deaths in wars and conflicts in the 20th century. Clingendael Institute, 2006.

LEITERITZ, Ralf. INTERnAtional POlitical ECONOMY: the STATE OF the ART. Colombia Internacional, N. 62, P. 50-63, 2005.

LUHNOW, David. The two Latin Americas: a continental divide between one BLOC THAT FAVORS STATE CONTROL AND ANOTHER THAT EMBRACES FREE MARKETS. The Wall Street Journal, 2014.

MACHLUP, Fritz. A history of thought on eConomic integration. London: Macmillan Press, 1977.

MALAMUD, Andres. A leAder Without followers? The GROWIng DiVergenCE Between the Regional and global performance of Brazilian foreign policy. Latin American Politics and Society, v. 53, N. 3, p. 1-24, 2011 в.

MALAMUd, Andres. Conceptos, teorías y debates sobre la INTEGRACIÓN regional. Norteamerica, 2011 A.

MAlamud, Andres. Mercosur turns 15: between rising rhetoric and declining achievement. Cambridge Review of International Affairs, v. 18, N. 3, P. 421-436, 2005. 
Research and conceptual cages in the International Political Economy of South American Ernesto Vivares • Lorena Herrera-Vinelli

MALAMUd, Andres; GARDINI, Gian LucA. Has Regionalism Peaked? The Latin American quagmire and its lessons. The International Spectator, v. 47, N. 1, P. 116-33, 2012.

MANSFIELD, Edward; MILNER, Helen (Eds.). The political economy of regionalism. New York: Columbia University Press, 1997.

MitRANY, David. A working peace system. London: Royal Institute of International AfFairs, 1966.

NYE, Joseph. Pan Africanism and East African integration. Cambridge: HarVARd University Press, 1965.

NYE, Joseph. The paradox of American power: why the World's only superpower can't go it alone. New York: Oxford University Press, 2002.

PAyne, Anthony. The global politics of unequal sevelopment. London: Palgrave, 2005.

PAyne, Anthony. The United States and its enterprise for the Americas. In: GAMBLE, Andrew; PAYNE, Anthony. Regionalism and world order. LONDON: MaCMILLAN, 1996.

Payne, Anthony. The new regional politics of development. New York: Palgrave, 2004.

PAyne, Anthony; Phillips, Nicola (Eds.). Development. London: Polity, 2010.

Petras, James; Veltmeyer, Henry. The rise and demise of extractive Capitalism. The Unz Review. 2012. Avallable In: hTtP://www.unz.com/JPEtras/ THE-RISE-AND-DEMISE-OF-EXTRACtIVE-CAPITALISM/ AcCesS: 16 MAR. 2019.

POLANYI, Karl. The great transformation: the political and economic origins of our time. Boston: Beacon Press, 2001. 
Research and conceptual cages in the International Political Economy of South American Ernesto Vivares • Lorena Herrera-Vinelli

QUiliconi, Cintia. Competitive diffusion of trade agreements in Latin America. International Studies Review, v. 16, N. 2, P. 240-251, 2014.

QUiliCONI, Cintia; SAlgado, Raúl. The South American Regionalisms: A SHIFT OR THE RETURN OF ECONOMIC INTEGRATION. In: VIVARES, ERNESTO (Ed.). Regionalism, deVelopment and the post-commodities boom in South America. New York: Palgrave Macmillan, 2018.

Reid, Michael. Forgotten continent: the Battle for Latin American Soul. New Haven: Yale University Press, 2009.

RigGiROZZI, Pia. Region, Regionness and regionalism in Latin America: towards a new synthesis. Latin American Trade Network, 2010.

RIGGIROZZI, PiA. Region, Regionness, AND REgIONAlism: towards a NEW synthesis. New Political Economy, v. 17, n. 4, p. 1-23, 2012.

ROBSON, Peter. The new regionalism and deVeloping countries. Journal of Common Market Studies, v. 31, N. 3, p. 329-384, 1993.

SANAHUja, José Antonio. Del 'Regionalismo abierto' al regionalismo post-liberal. Crisis y cambio en la integración regional en América Latina". Anuario de la integración de América Latina y el Gran Caribe 2008-2009, Coordinadora Regional de Investigaciones Económicas y Sociales, 2009.

SANAHUja, José Antonio. La construcción de una Región: Suramérica y el regionalismo posliberal. In: SANAHUjA, José Antonio; CienFUEGOS, Mateo (Eds.). Una Región en CONSTRUCCIÓN: UNASUR Y LA INTEGRACIÓN EN América del Sur. Madrid: Fundación CIDOB, 2010.

SAUTU, Ruth. Todo es teoría: objetivos y métodos de InVEStigación. Buenos Aires: Ediciones Lumiere, 2003. 
Research and conceptual cages in the International Political Economy of South American Ernesto Vivares • Lorena Herrera-Vinelli

SCHUldT, Jürgen; ACOStA, Alberto. Petróleo, rentismo y subdesarrollo. ¿UNA MALdición SIN SOlUCión? In: CAAP y CLAES (ORgS). Extractivismo, POLÍtICA Y SOCIEDAd. QUITO: CAAP y CLAES, 2009.

ShAW, Timothy M. Africa renaissance/African alliance: towards neW REGIONALISM AND NEW REALISM IN THE GREAT LAKES THE START OF THE TWENTY-FIRST Century. Politeia, v. 17, N. 3, P. 60-74, 1988.

ShaW, Timothy M. NeW regionalism in Africa in the new millennium: comparative perspectives on Renaissance, Realism and/or Regressions. New Political Economy, v. 5, N. 3, P. 399-414, 2000.

SHAW, Timothy; MARCHAND, Marianne; BOAS, Morten (Eds.). The political economy of Regions And Regionalism. London: Palgrave Macmillan UK, 2005.

Sil, Rudra; KATZenstein, Peter (Eds.). Beyond paradigms: analytic eclecticism in the study of World politics. New York: Palgrave Macmillan, 2010.

SMith, Karen. Can it be home-grown? Challenges to deVeloping IR theory in the global south. In: International Studies Association, 2006, San Diego. SODERBAUM, Fredrik. Conceptualizing region, Regionalism and REGIONALIZATION. 2012.

SODERBAUM, Fredrik. Introduction: theories of new Regionalism. In: SÖderbaum, Fredrik; SHAW, Timothy M. (Eds.). Theories of new regionalism. Houndmills: Palgrave Macmillan, 2003.

SOderbaum, Fredrik. Rethinking Regionalism. Basingstoke: Palgrave MACMILLAN, 2015.

SODERBAUM, Fredrik. The international political eConomy of Regionalism. IN: PHILLIPS, Nicola (Ed.). Globalizing international POlitical eCONOMY. London: Palgrave MacMillan, 2005. 
Research and conceptual cages in the International Political Economy of South American Ernesto Vivares • Lorena Herrera-Vinelli

SODERBAUM, FredriK. What's Wrong With RegIONAL INTEGRATION? THE problem of Eurocentrism. Working Papers N64: RSCAS, 2013.

SODERBAUM, FredriK; SHAW, Timothy (EdS.). Theories OF NEW RegIONALISM. Basingstoke: Palgrave MacMillan, 2003.

STEin, Arthur A. Neoliberal institutionalism. In: REUS-SMith, Christian; SNIDAL, Duncan (Eds.). The Oxford Handbook of international relations. Estados Unidos: Oxford University Press, 2008.

Strange, Susan. Casino capitalism. New York: Manchester University PRESS, 1986.

StRAnGE, Susan. States and markets. New York: Continuum, 1988.

SVAMPA, Maristella. "Consenso de los commodities" y lenguajes de valoración en América Latina. Nueva Sociedad, N. 244, P. 30-46, 2013.

TAYlor, ian. China's new role in África. New York: Lynne Rienner Publishers, 2010.

tiCkner, Arlene. Hearing Latin American voices in international relations Studies. International Studies Perspectives, v. 4, N. 4, p. 325-350, 2003.

TORRENT, Ramon. Regional INTEgRation InStRUmentS AND DIMENSIONS: AN analytical fRAmEWork. In: DEVLIN, Robert; ESTEVADEORDAL, AntonI (EdS.). BRIDGes for DEVELOPMENT: POLICIES AND INSTITUTIONS FOR TRADE AND integration. Washington, D.C.: Inter-American DeVelopment Bank. 2003.

ViOTTI, Paul; KaUpPI, Mark (Eds.). International relations theory. United States: Pearson, 2012.

WALtZ, Kenneth N. Theory of international politics. United States: AdDISON-WesLeY, 1979. 
Research and conceptual cages in the International Political Economy of South American Ernesto Vivares • Lorena Herrera-Vinelli

WaltZ, Kenneth N. Man, the State and war. New York: Columbia UnIVERSITY PRESS, 2001.

WeBER, Max. The protestant ethic and the spirit of capitalism. London: ROUTLEDGE, 2001. 